\title{
Is the inflammasome a potential therapeutic target in renal disease?
}

\author{
Clare M Turner ${ }^{1}$, Nishkantha Arulkumaran ${ }^{1,2^{*}}$, Mervyn Singer ${ }^{2}$, Robert J Unwin ${ }^{3}$ and Frederick WK Tam ${ }^{1}$
}

\begin{abstract}
The inflammasome is a large, multiprotein complex that drives proinflammatory cytokine production in response to infection and tissue injury. Pattern recognition receptors that are either membrane bound or cytoplasmic trigger inflammasome assembly. These receptors sense danger signals including damage-associated molecular patterns and pathogen-associated molecular patterns (DAMPS and PAMPS respectively). The best-characterized inflammasome is the NLRP3 inflammasome. On assembly of the NLRP3 inflammasome, post-translational processing and secretion of pro-inflammatory cytokines IL-1 $\beta$ and IL-18 occurs; in addition, cell death may be mediated via caspase-1. Intrinsic renal cells express components of the inflammasome pathway. This is most prominent in tubular epithelial cells and, to a lesser degree, in glomeruli. Several primary renal diseases and systemic diseases affecting the kidney are associated with NLRP3 inflammasome/IL-1//LL-18 axis activation. Most of the disorders studied have been acute inflammatory diseases. The disease spectrum includes ureteric obstruction, ischaemia reperfusion injury, glomerulonephritis, sepsis, hypoxia, glycerol-induced renal failure, and crystal nephropathy. In addition to mediating renal disease, the IL-1/ IL-18 axis may also be responsible for development of CKD itself and its related complications, including vascular calcification and sepsis. Experimental models using genetic deletions and/or receptor antagonists/antiserum against the NLRP3 inflammasome pathway have shown decreased severity of disease. As such, the inflammasome is an attractive potential therapeutic target in a variety of renal diseases.
\end{abstract}

Keywords: Inflammasome, NLRP3, Renal disease, IL-1 $\beta$, IL-18, PAMPs, DAMPs, P2X 7 R

\section{Introduction}

Inflammation is central to the pathogenesis of many renal diseases. The innate immune system, a first line defense against pathogens, is usually involved in the initiation and propagation of inflammation. It is activated by a series of germ-line encoded pattern recognition receptors (PRRs) that allow discrimination of 'self' from 'non-self' antigens. PRRs recognize conserved pathogen-associated molecular patterns (PAMPs) on invading organisms, or respond to host-derived danger-associated molecular patterns (DAMPs) released in response to stress, tissue injury, or cell death. Several classes of PRRs have been identified, including transmembrane Toll-like receptors (TLR), C-type lectin receptors (CLRs), the retinoic acid inducible gene-I (RIG-I) receptors, intracellular Nod-like receptors (NLRs),

\footnotetext{
* Correspondence: nish_arul@yahoo.com

${ }^{1}$ Imperial College Kidney and Transplant Institute, Hammersmith Hospital, Imperial College London, London, UK

${ }^{2}$ Bloomsbury Institute of Intensive Care Medicine, Division of Medicine, University College London, WC1E 6BT London, UK

Full list of author information is available at the end of the article
}

and the recently identified HIN-200 receptors [1-3]. Extracellular PAMPs and DAMPs are recognized by TLRs and CLRs, whereas NLRs and RIGs recognize intracellular molecular patterns (Table 1).

PRRs are expressed primarily by innate immune cells, but also by endothelial and epithelial cells. The innate immune system is 'primed' by activation of PRRs by PAMPs or DAMPs, which leads to activation of numerous proinflammatory transcription factors, the best characterized being nuclear factor kappa-B (NF-kB) and activator protein-1 (AP-1), with subsequent transcription of multiple mediators (including cytokines and chemokines) and receptors.

A key mechanism responsible for the post-transcriptional processing and release of mature cytokines is formation of the inflammasome complex. The human genome encodes 23 NLR proteins broadly divided into NLRP (with a pyrin domain) and NLRC (with a caspase recruitment domain), a subset of which are capable of forming an inflammasome complex. This multiprotein 
Table 1 Activators of the inflammasome

\begin{tabular}{|c|c|c|c|c|c|}
\hline \multicolumn{2}{|c|}{ Sterile activators } & \multicolumn{4}{|c|}{ Pathogen activators (PAMPS) } \\
\hline DAMPs & Environment derived & Bacteria derived & Virus-derived & Fungus-derived & Protozoa-derived \\
\hline$\overline{\text { ATP }}$ & Alum & Pore-forming toxins & RNA & $\beta$-glucans & Hemozoin \\
\hline Cholesterol crystals & Asbestos & Lethal toxin & M2 protein & Hyphae & \\
\hline MSU/CPPD crystals & Silica & Flagellin/rod proteins & & Mannan & \\
\hline Glucose & Alloy particles & MDP & & Zymosan & \\
\hline Amyloid $\beta$ & UV radiation & RNA & & & \\
\hline Hyaluronian & Skin irritants & DNA & & & \\
\hline
\end{tabular}

Activators of the inflammasome are divided into 2 categories: Sterile activators include host derived DAMPs and environment derived molecules, and pathogen activators include PAMPs derived from bacteria, virus, fungi and protozoa.

Abbreviations: CPPD Calcium pyrophosphate dehydrate, DAMP Damage-associated molecular pattern, MDP Muramyl dipeptide, MSU Monosodium urate, PAMP Pathogen associated molecular pattern

cytosolic complex oligomerizes to provide a platform for processing and release of cytokines. Seven cytoplasmic receptors form an inflammasome complex: NLRP1 (NLR family, pyrin domain containing 1 , also called NALP1), NLRP3 (also called NALP3 or cryopyrin), NLRP6, NLRP12, NLRC4 (NLR family, caspase recruitment domain (CARD) containing 4, also called IPAF), AIM2 (absent in melanoma-2), and RIG-1 (retinoic acid inducible gene 1). Of these receptors, the NLRP3 inflammasome is the best characterized.

\section{Review}

\section{The NLRP3 inflammasome}

This large multiprotein complex $(>700 \mathrm{KDa})$ forms in response to diverse PAMPs, including lipopolysaccharide (LPS), peptidoglycan, bacterial DNA, viral RNA and fungi, and DAMPs such as monosodium urate crystals (MSU), calcium pyrophosphate dehydrate, cholesterol crystals, amyloid $\beta$, hyaluronan and, possibly, glucose [1] (Table 1).

Priming of the cell (signal 1) by activation of PRRs results in NFkB -dependent transcription of pro-IL-1 $\beta$ and upregulation of NLRP3. Assembly of the NLRP3 inflammasome relies on the adaptor molecule ASC (Apoptosis-associated Speck-like protein containing a $\mathrm{C}$-terminal caspase recruitment domain (CARD)). The ASC protein is composed of PYD (N-terminal pyrin domain) and CARD domains. The N-terminus of NLRP3 also contains a PYD that mediates homotypic binding with ASC via a PYD-PYD interaction. Through its CARD, ASC interacts with procaspase- 1 leading to autocatalytic activation of caspase-1. This results in processing of pro-IL-1 $\beta$ and pro-IL-18 to their active forms (IL-1 $\beta$ and IL-18) and their release (Figure 1).

The cell surface $\mathrm{P} 2 \mathrm{X}_{7}$ receptor $\left(\mathrm{P} 2 \mathrm{X}_{7} \mathrm{R}\right)$ facilitates assembly of the NLRP3 inflammasome [4-6]. ATP released into the extracellular milieu during inflammation is a potent stimulus for $\mathrm{P}_{2} \mathrm{X}_{7} \mathrm{R}$ activation [7-9]. This results in formation of an ion pore and $\mathrm{K}^{+}$efflux, with reduction in intracellular $\mathrm{K}^{+}$, a key step in inflammasome activation [10]. Activation of $\mathrm{P}_{2} \mathrm{X}_{7} \mathrm{R}$ by LPS and ATP results in MyD88-dependent NFkB activation (signal 2), and transcription of pro-IL-1 $\beta$ [11]. Following LPS priming of monocytes, $\mathrm{P}_{2} \mathrm{X}_{7} \mathrm{R}$ activation stimulates $\mathrm{NADPH}$ oxidase generation of superoxide anions, thereby facilitating NLRP3 activation [12].

\section{Other inflammasomes}

NLRP1 was the first inflammasome to be described and is activated following cleavage by the lethal toxin from Bacillus anthracis [13]. The NLRP1 inflammasome has its own CARD, so can bypass the requirement of the adapter molecule ASC for inflammasome activation (Figure 2). Cleavage by the anthrax toxin directly activates CARD, leading to activation of caspase-1 [13]. An alternative mechanism of NLRP1 activation is by the toxin inhibiting p38 mitogen-activated protein kinase and Akt kinase, leading to opening of the connexion channel for ATP release, resulting in $\mathrm{P}_{2} \mathrm{X}_{7} \mathrm{R}$ signaling [14]. There are similarities with the mechanism of activation of the NLRP3 inflammasome.

A second class of inflammasomes contains members of the PYHIN family, rather than NLRs. These are characterised by N-terminal PYD and C-terminal HIN-200 (hemopoetic interferon-inducible nuclear antigen with 200 repeats) DNA binding domains. Examples include AIM2 and Interferon- $\gamma$ inducible protein 16 (IFI16) inflammasomes. These lack a CARD domain and require ASC for recruitment of pro-caspase-1 to form a stable inflammasome complex. The PYD domain interacts with the PYD domain of ASC. Following detection of bacterial or viral dsDNA, AIM2 and IFI16 inflammasomes assemble with subsequent secretion of IL- $1 \beta$ and IL-18 [15], which is severely impaired in mice deficient in AIM2 that are highly susceptible to Mycobacterium tuberculosis infection [16]. AIM2 can recognise self-DNA, but this is limited under steady-state conditions because of its cytosolic location. In conditions where self-DNA is 


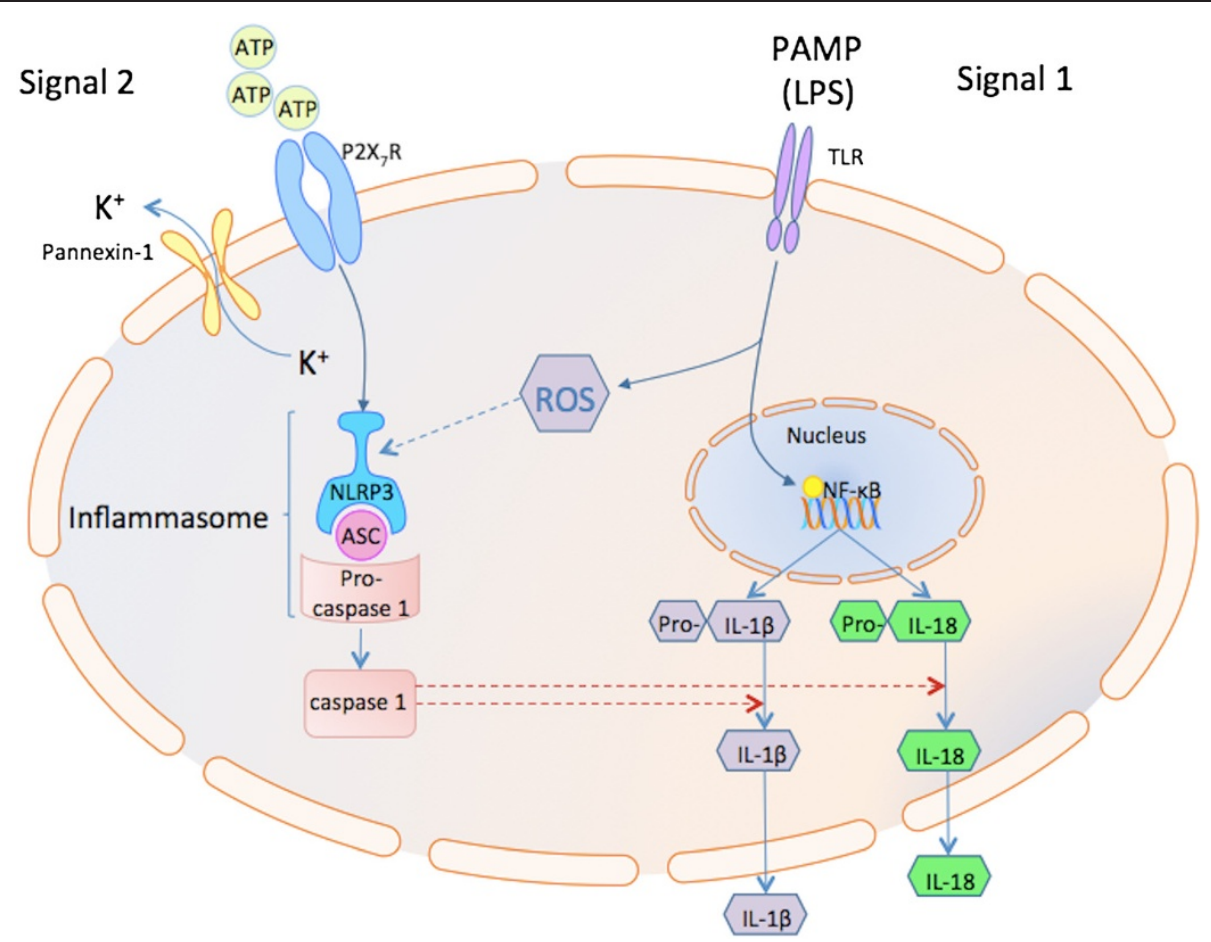

Figure 1 Model of NLRP3 inflammasome activation. NLRP3 is activated by a vast array of stimuli including extracellular pathogen PAMPS such as bacterial LPS via pattern recognition receptors (PRR) such as Toll-like receptors (TLR) and DAMPs. This comprises signal 1 and leads to synthesis of the cytokine precursor pro-IL-1 $\beta$ via NF-KB and other components of the inflammasome such as NLRP3 itself. Many of the known activators of the inflammasome generate ROS which can bind to NLRP3 and this appears necessary for its activation. Extracellular ATP binding to the P2X7 receptor (P2X7R) comprises signal 2. This promotes the recruitment and opening of the pannexin-1 pore channel which causes rapid $\mathrm{K}^{+}$efflux, another event which appears necessary for NLRP3 activation. NLRP3 assembly occurs when, through its pyrin domain, NLRP3 binds to the pyrin domain on an ASC molecule which then binds to pro-caspase-1 via its CARD domain. This leads to cleavage of pro-caspase-1 and subsequent cleavage of pro-IL-1 $\beta$ and pro-IL-18 to their active forms. Abbreviations: DAMP, damage-associated molecular pattern; LPS, lipopolysaccharide; ROS, reactive oxygen species; PAMP, pathogen-associated molecular pattern; PRR, pattern recognition receptor; TLR, toll-like receptor; PYD, pyrin domain.

not cleared from the extracellular compartment, it is likely that DNA can activate AIM2 and drive inflammation. Of note, HIN-200 proteins are considered a candidate locus for susceptibility to lupus [17]. In contrast to AIM2, IFI16 is located within the nucleus; the mechanism by which it discriminates between self and viral DNA in the nucleus is currently unknown.

The NLRC4 inflammasome interacts directly with procaspase-1 via homotypic CARD interactions, leading to processing of caspase-1. This inflammasome complex plays an essential role in the innate immune response to the bacterial proteins flagellin and PrgJ [18]. Direct binding of NLRC4 with flagellin or PrgJ has not been shown; however, the proteins of the NAIP family (NLR family, apoptosis inhibitor) act as immune sensors that can interact with, and control, NLRC4 activation. The NAIP2-NLRC4 complex associates with PrgJ, while the NAIP5-NLRC4 complex associates with flagellin [19]. This suggests that distinct NAIP proteins allow the NLRC4 inflammasome to differentiate among different bacterial ligands.
The NLRP6 inflammasome associates with ASC, inducing caspase-dependent processing and release of IL-1ß. At the mRNA level NLRP6 is highly expressed in mouse liver, kidney and small intestine, and plays a central role in modulating inflammatory responses in the gut to allow recovery from intestinal epithelial damage, tumorigenesis, and in controlling the composition of the gut microflora to prevent colonization by harmful bacteria [20,21]. Data on NLRP6 and renal disease are limited and warrant further study.

The NLRP12 inflammasome is expressed in human myeloid cells. It acts as a negative regulator of inflammation by reducing $\mathrm{NFK}_{\mathrm{B}} \mathrm{B}$ activation and inhibiting chemokine expression through ATP hydrolysis [22]. NLRP12 also reduces NFKB activation by (i) TLR-signaling molecules MyD88, IRAK-1 (type I interleukin-1 receptorassociated protein kinase), and TRAF6 (TNF receptor (TNFR)-associated factor), and (ii) the TNFR signaling molecules TRAF2 and RIP1, but not the downstream NFkB subunit p65 [23]. NLRP12, like NLRP6, can 


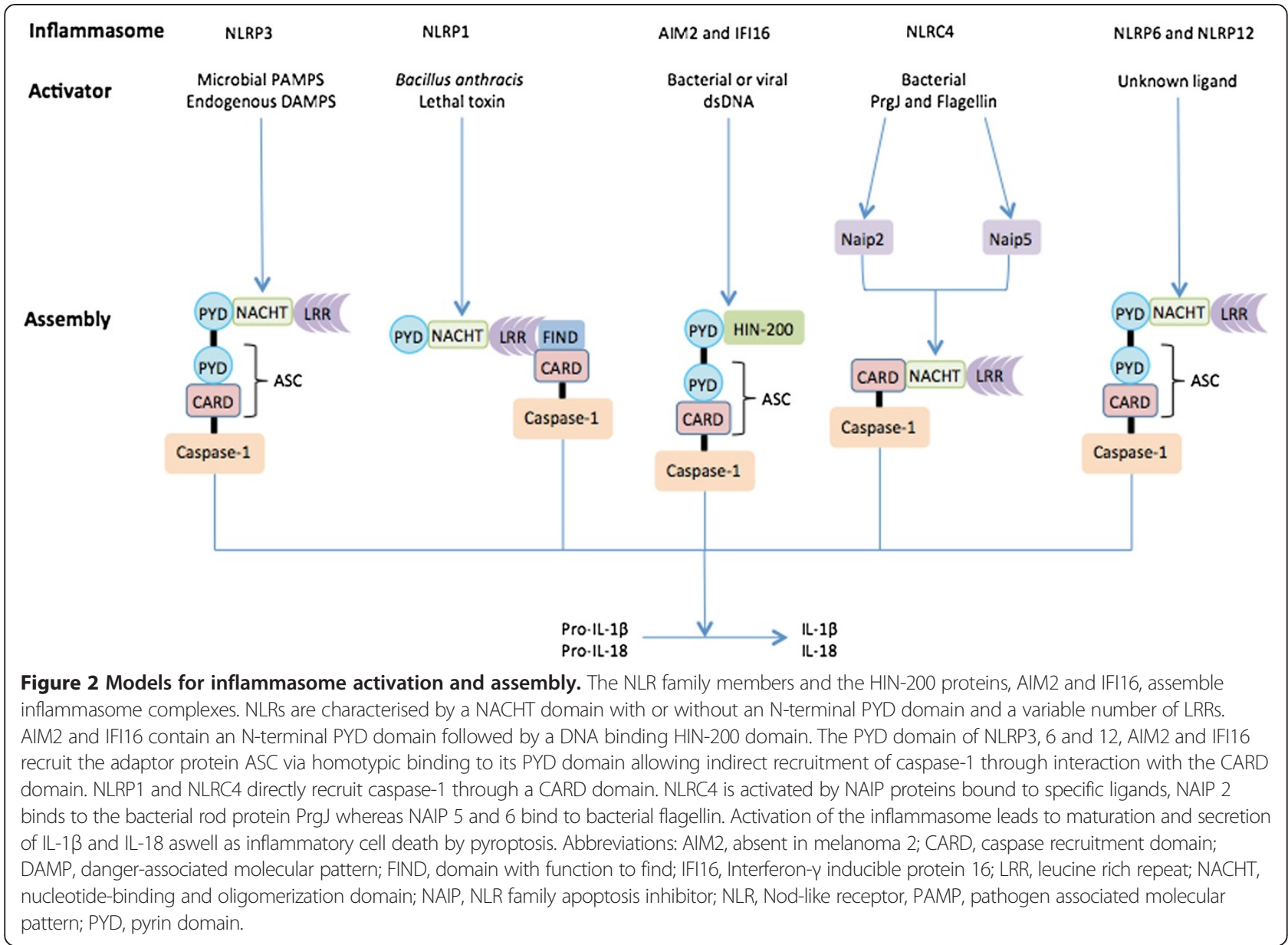

contribute to the maintenance of intestinal epithelium, since mice deficient in NLRP12 are more susceptible to colonic inflammation and tumorigenesis [24].

\section{Processing of IL-1 $\alpha$, IL-1 $\beta$, IL-18, and caspase-1}

IL-1 is a key cytokine in many inflammatory diseases. Activation of MAPK and NFKB signal transduction pathways is central to the diverse actions of IL-1, which include production and/or release of nitric oxide (NO), cyclooxygenase-2 (COX-2) and superoxide products, and other pro-inflammatory mediators $[25,26]$.

IL-1 has two biologically active isoforms, IL- $1 \alpha$ and IL-1 $\beta$, which bind to the same receptors $[27,28]$. Both are produced as $31 \mathrm{kDa}$ precursors that are stored within the cytosol. Pro-IL- $1 \alpha$ is constitutively expressed, whereas pro-IL-1 $\beta$ is transcribed in response to an inflammatory or infectious stimulus [25]. Various inflammatory stimuli engage with the PRR receptors of immune cells, activating MAPK and/or NFKB signalling cascades, and resulting in the synthesis of pro-IL- $1 \beta$ from its pro-IL- $1 \beta$ precursor, which is also stored within the cytosol.
IL- $1 \alpha$ release is typically described as being passive, as a consequence of non-apoptotic cell death [29]. IL-1 $\alpha$ processing depends on calpain protease activity [30]. The activation of calpain-like may be NLRP3-inflammasome/caspase-1 dependent or independent, depending on the type of NLRP3 agonist [31]. Caspase-1 knockout cells are unable to secrete IL- $1 \alpha$ in response to soluble NLRP3 stimuli while caspase inhibitors have no effect, suggesting that the catalytic activity of caspase- 1 is not required [32]. This protease- independent function of caspase- 1 in the release of IL- $1 \alpha$ is not well established.

Although IL- $1 \alpha$ has similar biological activity in its precursor and cleavage product forms; in contrast, IL-1 $\beta$ is only active after cleavage to its $17 \mathrm{kDa}$ mature form. Caspase-1 is crucial for processing of intracellular proIL-1 $\beta$, although extracellular pro-IL-1 $\beta$ can be processed by several proteases, including serine proteinase 3 and the metalloproteinases MMP-2 and MMP-9 [33,34].

Caspase- 1 is produced from the constitutively expressed $45 \mathrm{kDa}$ cytoplasmic pro-enzyme, pro-caspase- 1 . This requires post-translational processing to form 20 and $10 \mathrm{kDa}$ 
forms of active caspase-1 [34], and occurs following assembly of the NLRP3 inflammasome. Proteolytic activation of IL-1 $\beta$ occurs within the inflammasome complex. Mature IL-1 $\beta$ is released into the extracellular space by exocytosis or loss of membrane integrity [35].

Synthesis and release of IL-18 is closely linked to IL-1. IL-18 is a key mediator in the host response to infection and the inflammatory response $[27,36]$. It is also constitutively produced as a precursor, pro-IL 18 [36], which is cleaved by either caspase- 1 or proteinase- 3 into its active form released into the extracellular space along with mature IL-1 $\beta$.

Contact with a DAMP or PAMP ('signal 1') alone is insufficient for extracellular release of IL-1 $\beta$ and IL-18. An additional stimulus ('signal 2'), mediated by a variety of ligands including extracellular ATP, nigericin, bacterial toxins, hypotonic stress and $\mathrm{T}$ cells, is usually required for the extracellular release of active IL-1 $\beta$ and IL-18. However, the best-established stimulus for this posttranslational processing and release is ATP, acting via the $\mathrm{P} 2 \mathrm{X}_{7} \mathrm{R}[33,36]$.

\section{Effects of IL-1a, IL-1 $\beta$, IL-18}

Il-1 $\beta$ has diverse functions relating to its unique ability to regulate inflammation at both the nuclear and membrane receptor levels. Unlike other cytokines, the effects of IL-1 $\beta$ on lymphocytes are largely indirect, mediated by the induction of gene expression and synthesis of cyclooxygenase-1 (COX-2), prostaglandin-E2, platelet activating factor, NO, and IL-6 [25,26]. In turn, these mediators result in fever, vasodilation, hyperalgesia, and a repertoire of immune cell functions. IL- $1 \alpha$ and IL-1 $\beta$ also act as co-stimulatory molecules of $\mathrm{T}$ cells with an antigen, and may contribute to $\mathrm{T}$ cell polarization (early Th17 differentiation in vivo and Th17-mediated autoimmunity) [37].

IL-1 induces angiogenesis via upregulation of VEGF. This mechanism is mediated primarily via the $\mathrm{PI} 3-\mathrm{K} / \mathrm{mTOR}$ pathway in renal mesangial cells [38], and may be an important protective mechanism in ischemic injury. However, excessive IL-1 may be detrimental. IL-1 $\beta$ induces the expression of adhesion molecules, including intercellular adhesion molecule- 1 and vascular cell adhesion molecule1 , on mesenchymal and endothelial cells [39-42]. IL-1 knockout (KO) mice and antagonist-treated rats develop significantly less infiltration of polymorphonuclear leukocytes, and have less severe renal histological and biochemical derangement, in ischemia-reperfusion (I-R) injury [43-45]. Deficiency or neutralization of IL-1 confers a similar protective effect in experimental glomerulonephritis (GN) [46-48].

Excessive tissue destruction may be mediated in part by IL- $1 \alpha$. Unlike IL- $1 \beta$, IL- $1 \alpha$ is active in its precursor form. This active precursor is constitutively expressed in epithelial cells [49] and the inflammatory resulting from cell necrosis may be mediated by surface IL-1 $\alpha$ [29]. Activity of IL- $1 \alpha$ is controlled by endogenous expression of intracellular IL-1Ra, which prevents signal transduction [50], consistent with findings in a model of renal I-R injury: the number of apoptotic tubular cells was lower in IL-1RA-treated animals $24 \mathrm{~h}$ after ischemia, which was paralleled by a Bax/Bcl-2 mRNA ratio towards antiapoptotic effects [45]. Biologically active IL-1 $\alpha$ is also expressed on the membrane of monocytes and B-lymphocytes [51,52]. In addition, the induction of many genes by IFN-gamma (INF- $\gamma$ ), including HLA-DR, ICAM-1, IL-18BP, and genes mediating its antiviral activity, depends on basal IL-1 $\alpha$ but not IL-1 $\beta$ [53].

IL-18 (previously known as INF- $\gamma$ inducing factor) is a member of the IL-1 cytokine family, with many properties distinguishing it from IL- $1 \alpha$ and IL- $1 \beta$. IL-18 is primarily expressed by macrophages and dendritic cells, but also by epithelial cells throughout the body $[54,55]$. One of the key features of IL-18 is its ability to induce INF- $\gamma$ production [55] and subsequent T cell polarization [56,57]. IL-18 plays an important role in the TH1 response, primarily by its ability to induce IFN- $\gamma$ production in $\mathrm{T}$ cells and natural killer cells [58]. Fas ligand-mediated cell death is also IL-18-dependent [59,60], and IL-18 neutralization is associated with a reduction in renal tubular apoptosis in unilateral ureteric obstruction (UUO) and I-R injury $[60,61]$. As well as to these distinguishing features, IL-18 also shares properties with other cytokines, including increases in cell adhesion molecules and chemokines, and NO synthesis [62-65]. IL-18 deficiency or neutralization is associated with decreased immune cell infiltration and relatively preserved renal function in UUO, I-R injury, and GN [61,66-68].

\section{Cell death and pyroptosis}

Caspase- 1 activation and subsequent production of IL-1 $\beta$ and IL-18 has a biphasic effect; low levels cause cytokine production but, above a certain threshold, can lead to pyroptosis [69]. This is a catastrophic form of cell death commonly found in monocytes, macrophages and dendritic cells, with morphological characteristics of apoptosis and necrosis. Cell lysis occurs due to caspase-1-dependent pore formation in the cell membrane, disruption of the cellular ionic gradient, osmotic driven water influx, and cell swelling $[6,7]$. This leads to inflammasome activation, release of proinflammatory cytokines, damaged DNA, and metabolic enzymes and, ultimately, cellular disruption releasing other DAMPS. Release of mitochondria into the extracellular space results in discharge of ATP that acts as a DAMP.

An alternative mechanism of cell death relates to activation of the $\mathrm{P}_{2} \mathrm{X}_{7} \mathrm{R}$. Here, irreversible pore formation allows the non-selective passage of ions and hydrophilic 
solutes of up to $900 \mathrm{Da}$, resulting in colloido-osmotic cell lysis [33]. P2X $\mathrm{X}_{7} \mathrm{R}$-induced shrinkage depends on $\mathrm{K}^{+}$ efflux via $\mathrm{K}_{\mathrm{Ca} 3.1}$, a voltage-independent potassium channel activated by intracellular calcium, and a pathway of $\mathrm{Cl}^{-}$efflux distinct from that implicated previously in apoptosis [70].

\section{Regulation of the inflammasome}

Activation of the inflammasome results in a rapid and substantial inflammatory response. As such, the inflammasome is tightly regulated at both transcriptional and post-transcriptional levels. Basal expression of inflammasome components, in particular NLRP3, is relatively low [8]; pro-apoptotic pathways, such as FAS ligand-receptor interactions, are required to induce expression of ASC [9]. The subcellular location of inflammasome components facilitates its regulation. ASC is localized to the nucleus in quiescent cells, but it is recruited to the cytoplasm on cell activation [10].

Alternatively spliced inflammasome components generate protein variants with different activities. ASC has at least three different isoforms, one of which has an inhibitory effect on inflammasome activity [71]. Several proteins regulate inflammasome activity by sequestration of inflammasome components. Anti-apoptotic Bcl-2 proteins, including $\mathrm{Bcl}-2$ and $\mathrm{Bcl}-\mathrm{x}_{\mathrm{L}}$, interact with NLRP1 to prevent ATP binding and inflammasome activation [12]. The pyrin-only proteins (POP) and the pyrin-containing NOD (PYNOD) proteins inhibit inflammasome formation via inhibition of $\mathrm{NF}_{\kappa} \mathrm{B}$ and suppression of ASC, respectively [72,73]. Other inhibitory proteins include COP (CARD only protein), INCA (inhibitory CARD), and ICEBERG all three proteins contain a CARD and they are believed to act as decoys inhibiting formation of an active inflammasome [74].

\section{Drugs modulating the NLRP3 inflammasome /IL-1/IL-18 axis}

Growing evidence suggests that the inflammasome and the IL-1 $\beta / \mathrm{IL}-18$ axis play an integral part in the pathogenesis of many acute and chronic conditions, including gout, rheumatoid arthritis, atherosclerosis, Alzheimer's disease, diabetes mellitus, and, most recently, oxalate crystal nephropathy. Several components of the NLRP3 inflammasome have been implicated in renal disease (Table 2). Therapeutic interventions that modulate this pathway are being developed, and the functional significance of the inflammasome and the IL- $1 \beta / \mathrm{IL}-18$ axis in renal disease is of growing interest. Drugs inhibiting IL-1, $\mathrm{P} 2 \mathrm{X}_{7} \mathrm{R}$, and caspase- 1 have been developed, although to date only IL-1 inhibitors have been successful in clinical studies of rheumatoid arthritis (RA) and cryopyrinassociated periodic syndrome (CAPS).

\section{IL-1 inhibitors}

The clinical application of IL-1 inhibitors has been slow, because the first generation of inhibitors, the recombinant IL-1 receptor antagonists, has a short circulatory half-life and limited affinity for the IL-1 receptor. A large molar excess of recombinant IL-1ra is needed to antagonize endogenous IL-1 effectively.

Drugs inhibiting the action of IL-1 include recombinant human IL-1ra (Anakinra), a humanized monoclonal IL-1 $\beta$ antibody (Canakinumab), and a neutralising antibody against IL-1 $\alpha$ and IL-1 $\beta$ (Rilonacept). Anakinra competitively inhibits binding of IL-1 to the IL-1 receptor and has been successfully used in RA [99] and autoinflammatory syndromes [100]. Rilonacept is a dimeric protein consisting of the extracellular portion of the IL-1 receptor and the $F_{c}$ portion of human $\operatorname{IgG}_{1}$ [101]; it works by effectively neutralizing IL- $1 \alpha$ and IL-1 $\beta$. Preliminary data suggest it may be beneficial in patients with autoinflammatory syndromes $[102,103]$. Canakinumab, a monoclonal antibody against IL-1 $\beta$, has a longer half-life compared with the other antagonists, and may be useful in patients with RA and CAPS [104,105]. Other diseases that may benefit from IL-1 blockade include acute gout [106], diabetes mellitus [100], inflammatory lung disease [107], adult-onset Still's disease [108], and juvenile idiopathic arthritis [109].

\section{$P 2 X_{7} R$ antagonists}

Drugs inhibiting the $P 2 X_{7} R$ are currently in Phase 1 and 2 clinical trials [110]. At present there are no data to demonstrate a beneficial effect of $\mathrm{P}_{2} \mathrm{X}_{7} \mathrm{R}$ antagonism, although trials are still at an early stage. Preclinical data suggest $P 2 X_{7} R$ antagonists have a potential role in the treatment of inflammatory rheumatological [111,112], renal [78,113], and pulmonary diseases [114-116]. Although Phase 1 and 2 studies have demonstrated safety, preliminary studies have so far not shown clinical efficacy in the management of RA [117].

\section{Caspase-1 inhibitors}

Small molecule inhibitors of caspase-1 have been used in experimental models. Only pralnacasan (VX-740) and VX-765 have been used so far in patients; however, concerns about liver toxicity with prolonged use of pralnacasan have resulted in discontinuation of clinical trials in RA, psoriasis, and osteoarthritis [118]. A Phase 2 clinical trial of VX-765 (NCT00205465) has been completed, although the results have yet to be published [118].

\section{The inflammasome in renal disease}

There is a better understanding of the role of IL- 1 and IL-18 in renal disease, although the importance of the inflammasome in the activation and secretion of IL-1 $\beta$ and IL-18 has only been investigated recently. Several 
Table 2 Inflammasome and inflammatory renal diseases

\begin{tabular}{|c|c|c|c|c|c|}
\hline $\mathrm{P} 2 \mathrm{X7}$ & Disease & Species & Antagonist/genetic deletion & Effect & $\begin{array}{l}\text { Renal localization of } \\
\text { inflammasome component }\end{array}$ \\
\hline Harada [75] & TNF-a stimulation & Rat & - & NA & Mesangial cells \\
\hline Gonclaves [76] & $\begin{array}{l}\text { Unilateral ureteric } \\
\text { obstruction }\end{array}$ & Mouse & $\mathrm{P} 2 \mathrm{X}_{7}{ }^{-/-}$ & Beneficial & PTEC \\
\hline \multirow[t]{2}{*}{ Vonend [77] } & Hypertension & Rat & - & NA & Glomerular podocytes \\
\hline & Diabetes mellitus & & & & \\
\hline \multirow[t]{4}{*}{ Turner [78] } & \multirow{2}{*}{$\begin{array}{l}\text { Experimental } \\
\text { glomerulonephritis }\end{array}$} & Mouse & - & NA & Glomeruli and infiltrating macrophages \\
\hline & & Rat & & & Glomeruli \\
\hline & \multirow[t]{2}{*}{ Lupus nephritis } & Humans & - & NA & Glomeruli \\
\hline & & & & & PTEC \\
\hline \multirow[t]{2}{*}{ Taylor [70] } & \multirow{2}{*}{$\begin{array}{l}\text { Experimental } \\
\text { glomerulonephritis }\end{array}$} & Rat & Antagonist & \multirow[t]{2}{*}{ Beneficial } & - \\
\hline & & Mouse & $\mathrm{P} 2 \mathrm{X}_{7}{ }^{-/-}$ & & \\
\hline NLRP3 & Disease & Species & Antagonist/genetic deletion & Effect & $\begin{array}{l}\text { Renal localization of } \\
\text { inflammasome component }\end{array}$ \\
\hline Deplano [79] & Glomerulonephritis & Rat & $\begin{array}{l}\text { Genetic susceptible strain } \\
\text { (cf. Protected strain) }\end{array}$ & NA & $\begin{array}{l}\text { Glomeruli and bone marrow } \\
\text { derived macrophages }\end{array}$ \\
\hline Vilaysane A [80] & $\begin{array}{l}\text { Non-diabetic } \\
\text { acute and chronic } \\
\text { kidney diseases }\end{array}$ & Human & NA & NA & PTEC \\
\hline Vilaysane A [80] & $\begin{array}{l}\text { Unilateral ureteric } \\
\text { obstruction }\end{array}$ & Mice & $\mathrm{NLRP}^{-/-}$ & Beneficial & PTEC \\
\hline lyer S [81] & $\begin{array}{l}\text { Ischaemia- reperfusion } \\
\text { injury }\end{array}$ & Mice & $\mathrm{NLRP3}^{-/-}$ & Beneficial & - \\
\hline Jalilian [82] & None & Dog & NA & NA & Epithelial cells \\
\hline IL-1 & Disease & Species & Antagonist/genetic deletion & Effect & $\begin{array}{l}\text { Renal localization of } \\
\text { inflammasome component }\end{array}$ \\
\hline Yamagishi H [83] & $\begin{array}{l}\text { Unilateral ureteric } \\
\text { obstruction }\end{array}$ & Mouse & IL-1 RA & Beneficial & PTEC \\
\hline \multirow[t]{2}{*}{ Haq M [44] } & \multirow{2}{*}{$\begin{array}{l}\text { Ischaemia- reperfusion } \\
\text { injury }\end{array}$} & \multirow[t]{2}{*}{ Mouse } & IL-1 RA & \multirow[t]{2}{*}{ Beneficial } & - \\
\hline & & & $\mathrm{IL}-1 \mathrm{R}^{-/-}$ & & \\
\hline Chen A [46] & IgA nephropathy & Mice & IL-1 RA & Beneficial & - \\
\hline Matsumoto [84] & Glomerulonephritis & Human & NA & NA & \\
\hline Tam [85] & Glomerulonephritis & Rat & NA & N/A & \\
\hline Lan [86] & Glomerulonephritis & Rat & IL-1RA & Beneficial & \\
\hline Karkar [87] & Glomerulonephritis & Rat & Antibody & Beneficial & \\
\hline Karkar [88] & Glomerulonephritis & Rat & IL-1RA and soluble IL-1R & Beneficial & \\
\hline \multicolumn{6}{|l|}{ Tam [89] } \\
\hline \multirow[t]{2}{*}{ Timoshanko JR [48] } & \multirow{2}{*}{$\begin{array}{l}\text { Crescentic } \\
\text { glomerulonephritis }\end{array}$} & \multirow[t]{2}{*}{ Mice } & $\mathrm{IL}-1 \beta^{-/-}$ & \multirow[t]{2}{*}{ Beneficial } & - \\
\hline & & & $\mid \mathrm{L}-1 \mathrm{R}^{-/-}$ & & \\
\hline \multirow[t]{5}{*}{ Lichtnekert [47] } & \multirow[t]{5}{*}{ Anti- GBM disease } & \multirow[t]{5}{*}{ Mice } & NLRP3 ${ }^{-/-}$ & No effect & Renal dendritic cells \\
\hline & & & Caspase $^{-1-}$ & No effect & \\
\hline & & & $\mathrm{ASC}^{-1-}$ & No effect & \\
\hline & & & $\mathbb{L L}-1 \mathrm{R} 1^{-/-}$ & Benefit & \\
\hline & & & $\|-18^{-/-}$ & $\begin{array}{l}\text { Mild } \\
\text { benefit }\end{array}$ & \\
\hline Schorlemmer H [90] & SLE-like disease & Mice & IL-1 RA & Beneficial & - \\
\hline \multirow[t]{2}{*}{ Furuichi [43] } & \multirow{2}{*}{$\begin{array}{l}\text { Ischaemia- reperfusion } \\
\text { injury }\end{array}$} & \multirow[t]{2}{*}{ Mice } & $\mathrm{IL}-1 \mathrm{a} \beta^{-/-}$ & \multirow[t]{2}{*}{ Beneficial } & glomeruli and cortical arterioles \\
\hline & & & $\mathrm{IL}_{-1} \mathrm{RA}^{-/-}$ & & \\
\hline
\end{tabular}


Table 2 Inflammasome and inflammatory renal diseases (Continued)

\begin{tabular}{|c|c|c|c|c|c|}
\hline Rusai [45] & $\begin{array}{l}\text { Ischaemia- reperfusion } \\
\text { injury }\end{array}$ & Rats & IL-1 RA & Beneficial & - \\
\hline \multirow[t]{2}{*}{ Granfeldt [91] } & \multirow[t]{2}{*}{ Endotoxaemia } & \multirow[t]{2}{*}{ Pigs } & \multirow[t]{2}{*}{ NA } & \multirow[t]{2}{*}{ NA } & $\begin{array}{l}\text { Endothelial cells of the cortical arterioles } \\
\text { were positive for } \mathrm{IL}-1 \beta\end{array}$ \\
\hline & & & & & $\begin{array}{l}\text { IL-1ra was detected in the glomerulus } \\
\text { and tubular cells }\end{array}$ \\
\hline Hertting [92] & E.Coli pyelonephritis & Mice & $\mathbb{I L}-1 \beta^{-/-}$ & Harmful & - \\
\hline Caspase-1 & Disease & Species & Antagonist/genetic deletion & Effect & $\begin{array}{l}\text { Renal localization of } \\
\text { inflammasome component }\end{array}$ \\
\hline \multirow[t]{2}{*}{ Homsi [93] } & \multirow[t]{2}{*}{ Glycerol- induced AKI } & \multirow[t]{2}{*}{ Rats } & \multirow[t]{2}{*}{ Caspase-1 inhibitor } & \multirow[t]{2}{*}{ Beneficial } & Constitutive tubular expression of IL-18 \\
\hline & & & & & Induction of tubular IL-1 $\beta$ \\
\hline \multirow[t]{3}{*}{ Wang [94] } & \multirow[t]{3}{*}{ Endotoxaemia } & \multirow[t]{3}{*}{ Mice } & Caspase $1^{-1-}$ & Beneficial & \multirow[t]{3}{*}{-} \\
\hline & & & IL-1 Ra & No effect & \\
\hline & & & IL-18 antiserum & No effect & \\
\hline Gauer [95] & None & Humans & NA & NA & $\begin{array}{l}\text { Collecting duct alpha- and beta-intercalated } \\
\text { cells express P2 } \mathrm{X}_{7}, \mathrm{IL}-18\end{array}$ \\
\hline \multirow[t]{2}{*}{ Edelstein [96] } & \multirow[t]{2}{*}{ Hypoxia } & \multirow[t]{2}{*}{ Mice } & Caspase $1^{-1-}$ & Beneficial & \multirow[t]{2}{*}{ IL-18 in PTEC } \\
\hline & & & IL-18 binding protein & No effect & \\
\hline IL-18 & Disease & Species & Antagonist/genetic deletion & Effect & $\begin{array}{l}\text { Renal localization of } \\
\text { inflammasome component }\end{array}$ \\
\hline Bani-Hani A [68] & $\begin{array}{l}\text { Unilateral ureteric } \\
\text { obstruction }\end{array}$ & Mice & $\begin{array}{l}\text { Transgenic mice overexpressing } \\
\text { human IL-18-binding protein }\end{array}$ & Beneficial & TECs \\
\hline \multirow[t]{3}{*}{ Wu H [66] } & \multirow{3}{*}{$\begin{array}{l}\text { Ischaemia- reperfusion } \\
\text { injury }\end{array}$} & \multirow[t]{3}{*}{ Mice } & $\mid \mathrm{L}-18^{-/-}$ & Beneficial & \multirow[t]{3}{*}{ TECS } \\
\hline & & & IL-18 ${ }^{-/-}$BM chimera & Beneficial & \\
\hline & & & IL-18-binding protein & Beneficial & \\
\hline Sugiyama M [67] & $\begin{array}{l}\text { Bovine serum } \\
\text { albumin-induced } \\
\text { glomerulonephritis }\end{array}$ & Mice & $\mathrm{IL}-18 \mathrm{R}^{-/-}$ & Beneficial & - \\
\hline Kinoshita K [97] & Autoimmune disease & Mice & $\| \mathrm{L}-18 \mathrm{R}^{-/-}$ & Beneficial & - \\
\hline Wang [61] & $\begin{array}{l}\text { Ischaemia-reperfusion } \\
\text { injury }\end{array}$ & Rat & IL-18-binding protein & Beneficial & - \\
\hline Zhang [60] & $\begin{array}{l}\text { Unilateral ureteric } \\
\text { obstruction }\end{array}$ & Mice & $\begin{array}{l}\text { Overexpress human IL-18-binding } \\
\text { protein isoform } a\end{array}$ & Beneficial & - \\
\hline VanderBrink [98] & $\begin{array}{l}\text { Unilateral ureteric } \\
\text { obstruction }\end{array}$ & Mice & $\mathrm{IL}-18^{-/-}$ & NA & TECS \\
\hline$\overline{A S C}$ & Disease & Species & Antagonist/genetic deletion & Effect & $\begin{array}{l}\text { Renal localization of } \\
\text { inflammasome component }\end{array}$ \\
\hline lyer S [81] & $\begin{array}{l}\text { Ischaemia- reperfusion } \\
\text { injury }\end{array}$ & Mice & $\mathrm{ASC}^{-1-}$ & Beneficial & - \\
\hline
\end{tabular}

Abbreviations: PTEC Proximal tubular epithelial cells, NLRP3 Nod-like receptor protein 3, IL-1RA Interleukin 1 receptor antitagonist, ARF Acute renal failure, TEC Tubular epithelial cell, $B M$ Bone marrow.

primary renal diseases are associated with NLRP3 inflammasome activation. Similarly, many systemic diseases affecting the kidneys are associated with NLRP3 inflammasome/IL-1 $\beta / \mathrm{IL}-18$ axis activation (Table 2). These include UUO [68,76,80,83], I-R injury [43-45,61,66,81], GN [46-48,67,70,90,97,119], sepsis [91,92,94], CKD [80,120], hypoxia [96], glycerol-induced renal failure [93], and crystal nephropathy [121]. Apart from two studies of CKD of various aetiologies $[77,80]$ most of the disorders studied have been acute inflammatory diseases. Recent data suggests that the NLRP3 inflammasome is the principle cause of progressive renal failure in oxalate nephropathy [122]. P2X ${ }_{7}$ R, IL-1 $\beta$, IL-18, caspase-1, ASC, and NLRP3 are all associated with renal inflammation and injury (Table 2). Virtually every experimental model using genetic deletions and/or receptor antagonists/antiserum against the NLRP3 inflammasome pathway has shown decreased severity of disease, although publication bias cannot be excluded.

However, the functional significance of the inflammasome remains unclear in certain conditions. For instance, 
conflicting data exists with respect to ischaemia reperfusion injury. Whilst some reports describe a protective effect of IL-1 receptor blockade with Anakinra in ischemia-reperfusion injury $[45,81]$, others demonstrate no benefit on renal injury responses [123]. This may be due to NLRP3 mediated injury that is independent of inflammasome activity [123]. In such circumstances, pharmacological inhibition of downstream targets may be less effective.

Intrinsic renal cells express components of the inflammasome pathway (Table 2). This is most prominent in tubular epithelial cells and, to a lesser degree, in glomeruli. The precise mechanisms involving the NLRP3 inflammasome in disease relate to both systemic and local (renal) activation. Limited studies using global knockouts and bone marrow chimeras suggest that systemic production of cytokines may have a greater effect on renal injury [66]. Findings related to genetic deletion or inhibition of the NLRP3 inflammasome pathway includes decreases in local cytokines and chemokines, inflammatory cell infiltrate, and apoptosis. It remains likely that locally released DAMPs result in inflammasome activation, resulting in chemokine release and immune cell infiltration. Differences in immune cell regulation of the inflammasome affect the susceptibility and severity of autoimmune GN [79].

The role of NLRP3 inflammasome activation in human renal disease is still uncertain. Consistent with experimental data $\mathrm{P} 2 \mathrm{X}_{7} \mathrm{R}$ and NLRP3 are upregulated in lupus nephritis and non-diabetic CKD, respectively [80,119]. The most extensively studied component of the NLRP3 inflammasome in relation to renal disease is IL-18. Collecting duct alpha- and beta-intercalated cells express P2X 7 R and IL-18 under basal conditions [95]. An elevated serum IL-18 correlates with the development of diabetic nephropathy [124], while urine IL-18 is elevated in acute kidney injury associated with critical illness [125], cardiac surgery [126], and radiocontrast [127], supporting the notion that the inflammasome is intimately involved in wider inflammatory renal disease. Further studies investigating the NLRP3 inflammasome pathway in human disease are needed.

\section{Chronic kidney disease and inflammation}

In addition to mediating acute forms of renal injury and disease, the IL-1/IL-18 axis may also be responsible for development of CKD itself and its related complications. Accelerated atherosclerosis and vascular calcification is a hallmark feature in CKD [128]. Vascular inflammation plays a role in vascular calcification and IL-18 may have a distinct role in mediating vascular injury among patients with advanced kidney disease. Basal levels of IL-18 are elevated in patients on maintenance haemodialysis [129]. The mechanism behind increased IL-18 production may relate to elevated levels of circulating MCP-1 in patients with CKD [130]. IL-18, through production of INF- $\gamma$, results in inflammation-related vascular injury, atherosclerotic plaque formation, and plaque instability [131-133]. IL-18 levels correlate with aortic pulse wave velocity [134], a surrogate for aortic stiffness and a predictor of major adverse cardiovascular events among patients with CKD [135].

In addition to cardiovascular disease, sepsis accounts for the majority of critical care admissions and mortality among patients with end-stage kidney disease [136]. The underlying mechanism(s) behind the increased susceptibility to sepsis relates in part to altered levels of IL-1 and IL-1RA, and monocyte activity. Basal levels of IL-1 $\beta$, TNF $\alpha$, and IL- 6 are elevated in CKD and in dialysis patients [137]. The IL-1ra/IL-1 $\beta$ ratio is also elevated $[137,138]$. A higher IL-1ra/IL-1 $\beta$ ratio may participate in the complex immune disturbances by reducing the biological activity of this vital pro-inflammatory cytokine in playing a major role in the immune and inflammatory network.

Complications associated with CKD are clearly multifactorial and a greater understanding of the role of the NLRP3 inflammasome/IL-1/IL-18 axis in mediating these complications is required before any therapeutic strategy can be developed and applied.

\section{Conclusions}

The NLRP3 inflammasome is becoming increasingly recognized as integral to the pathogenesis of many renal diseases and their complications. However, much of our knowledge of the inflammasome is limited to experimental models, but we need to elucidate its role in human renal disease, especially in CKD and its complications. Moreover, apart from inhibitors of IL-1, therapeutic agents targeting the NLRP3 inflammasome pathway suitable for use in humans are still lacking. Yet the inflammasome is likely to prove to be key pathogenic mechanism in nephrology and should be the subject of more intensive research.

\footnotetext{
Abbreviations

Competing interests

Clare M Turner

None declared

Nishkantha Arulkumaran

Wellcome Trust pre-doctoral training fellowship
}

AIM2: Absent in melanoma 2; ARF: Acute renal failure; BM: Bone marrow; CARD: Caspase recruitment domain; CPPD: Calcium pyrophosphate dehydrate; DAMP: Damage-associated molecular pattern; FIND: Domain with function to find; IFI16: Interferon- $\gamma$ inducible protein 16; IL-1RA: Interleukin 1 receptor antagonist; LPS: Lipopolysaccharide; LRR: Leucine rich repeat; MDP: Muramyl dipeptide; MSU: Monosodium urate; NACHT: Nucleotidebinding and oligomerization domain; NAIP: NLR family apoptosis inhibitor NLR: Nod-like receptor; NLRP3: Nod-like receptor protein 3; PAMP: Pathogenassociated molecular pattern; PRR: Pattern recognition receptor; PTEC: Proximal tubular epithelial cells; PYD: Pyrin domain; ROS: Reactive oxygen species; TEC: Tubular epithelial cell; TLR: Toll-like receptor. 
Mervyn Singer

Robert J Unwin

Consultancy with AstraZeneca

Frederick Tam

Research project grants from Roche Palo Alto, AstraZeneca Limited, Cyclacel Limited and Baxter Biosciences

Consultancy for Roche Palo Alto and Baxter Biosciences

\section{Authors' contributions}

$C T$, NA, Writing manuscript, Figures, Tables. Writing manuscript, Tables. MS, RJU, FT, Editing manuscript. All authors read and approved the final manuscript.

\section{Author details}

Imperial College Kidney and Transplant Institute, Hammersmith Hospital, Imperial College London, London, UK. Bloomsbury Institute of Intensive Care Medicine, Division of Medicine, University College London, WC1E 6BT London, UK. ${ }^{3}$ UCL Centre for Nephrology, Division of Medicine, Royal Free Campus and Hospital, University College London, WC1E 6BT London, UK.

Received: 7 October 2013 Accepted: 7 January 2014

Published: 23 January 2014

\section{References}

1. Ferrari D, Wesselborg S, Bauer MK, Schulze-Osthoff K: Extracellular ATP activates transcription factor NF-kappaB through the P2Z purinoreceptor by selectively targeting NF-kappaB p65. J Cell Biol 1997, 139(7):1635-1643.

2. Kahlenberg JM, Lundberg KC, Kertesy SB, Qu Y, Dubyak GR: Potentiation of caspase- 1 activation by the $\mathrm{P} 2 \mathrm{X} 7$ receptor is dependent on TLR signals and requires NF-kappaB-driven protein synthesis. J Immunol 2005, 175(11):7611-7622.

3. Wewers MD, Sarkar A: P2X(7) receptor and macrophage function. Purinergic Signalling 2009, 5(2):189-195.

4. Bauernfeind F, Bartok E, Rieger A, Franchi L, Nunez G, Hornung V: Cutting edge: reactive oxygen species inhibitors block priming, but not activation, of the NLRP3 inflammasome. J Immunol 2011, 187(2):613-617.

5. Bergsbaken T, Fink SL, den Hartigh AB, Loomis WP, Cookson BT: Coordinated host responses during pyroptosis: caspase-1-dependent lysosome exocytosis and inflammatory cytokine maturation. J Immunol 2011, 187(5):2748-2754.

6. Miao EA, Rajan JV, Aderem A: Caspase-1-induced pyroptotic cell death Immunol Rev 2011, 243(1):206-214.

7. Fink SL, Cookson BT: Caspase-1-dependent pore formation during pyroptosis leads to osmotic lysis of infected host macrophages. Cell Microbiol 2006, 8(11):1812-1825.

8. Bauernfeind FG, Horvath G, Stutz A, Alnemri ES, MacDonald K, Speert D, Fernandes-Alnemri T, Wu J, Monks BG, Fitzgerald KA, et al: Cutting edge: NF-kappaB activating pattern recognition and cytokine receptors license NLRP3 inflammasome activation by regulating NLRP3 expression. J Immunol 2009, 183(2):787-791.

9. Shiohara M, Taniguchi S, Masumoto J, Yasui K, Koike K, Komiyama A Sagara J: ASC, which is composed of a PYD and a CARD, is up-regulated by inflammation and apoptosis in human neutrophils. Biochem Biophys Res Commun 2002, 293(5):1314-1318.

10. Bryan NB, Dorfleutner A, Rojanasakul Y, Stehlik C: Activation of inflammasomes requires intracellular redistribution of the apoptotic speck-like protein containing a caspase recruitment domain. J Immunol 2009, 182(5):3173-3182.

11. Liu Y, Xiao Y, Li Z: P2X7 receptor positively regulates MyD88-dependent NF-kappaB activation. Cytokine 2011, 55(2):229-236.

12. Bruey JM, Bruey-Sedano N, Luciano F, Zhai D, Balpai R, Xu C, Kress CL, BaillyMaitre B, Li X, Osterman A, et al: $\mathrm{BCl}-2$ and $\mathrm{BCl}-\mathrm{XL}$ regulate proinflammatory caspase-1 activation by interaction with NALP1. Cell 2007, 129(1):45-56

13. Levinsohn JL, Newman ZL, Hellmich KA, Fattah R, Getz MA, Liu S, Sastalla I, Leppla SH, Moayeri M: Anthrax lethal factor cleavage of Nlrp1 is required for activation of the inflammasome. PLoS Pathog 2012, 8(3):e1002638.

14. Ali SR, Timmer AM, Bilgrami S, Park EJ, Eckmann L, Nizet V, Karin M: Anthrax toxin induces macrophage death by p38 MAPK inhibition but leads to inflammasome activation via ATP leakage. Immunity 2011, 35(1):34-44.

15. Roberts TL, Idris A, Dunn JA, Kelly GM, Burnton CM, Hodgson S, Hardy LL, Garceau V, Sweet MJ, Ross IL, et al: HIN-200 proteins regulate caspase activation in response to foreign cytoplasmic DNA. Science 2009 323(5917):1057-1060.

16. Saiga H, Kitada S, Shimada Y, Kamiyama N, Okuyama M, Makino M Yamamoto M, Takeda K: Critical role of AIM2 in Mycobacterium tuberculosis infection. Int Immunol 2012, 24(10):637-644

17. Choubey D, Panchanathan R, Duan X, Liu H, Liu H: Emerging roles for the interferon-inducible p200-family proteins in sex bias in systemic lupus erythematosus. J Interferon Cytokine Res 2011, 31(12):893-906.

18. Zhao Y, Yang J, Shi J, Gong YN, Lu Q, Xu H, Liu L, Shao F: The NLRC4 inflammasome receptors for bacterial flagellin and type III secretion apparatus. Nature 2011, 477(7366):596-600.

19. Kofoed EM, Vance RE: Innate immune recognition of bacterial ligands by NAIPs determines inflammasome specificity. Nature 2011, 477(7366):592-595.

20. Lech M, Avila-Ferrufino A, Skuginna V, Susanti HE, Anders HJ: Quantitative expression of RIG-like helicase, NOD-like receptor and inflammasomerelated mRNAs in humans and mice. Int Immunol 2010, 22(9):717-728.

21. Chen GY, Liu M, Wang F, Bertin J, Nunez G: A functional role for Nlrp6 in intestinal inflammation and tumorigenesis. J Immunol 2011 186(12):7187-7194

22. Ye Z, Lich JD, Moore CB, Duncan JA, Williams KL, Ting JP: ATP binding by monarch-1/NLRP12 is critical for its inhibitory function. Mol Cell Biol 2008, 28(5):1841-1850.

23. Williams KL, Lich JD, Duncan JA, Reed W, Rallabhandi P, Moore C, Kurtz S, Coffield VM, Accavitti-Loper MA, Su L, et al: The CATERPILLER protein monarch-1 is an antagonist of toll-like receptor-, tumor necrosis factor alpha-, and Mycobacterium tuberculosis-induced pro-inflammatory signals. J Biol Chem 2005, 280(48):39914-39924.

24. Allen IC, Wilson JE, Schneider M, Lich JD, Roberts RA, Arthur JC, Woodford RM, Davis BK, Uronis JM, Herfarth HH, et al: NLRP12 suppresses colon inflammation and tumorigenesis through the negative regulation of noncanonical NF-kappaB signaling. Immunity 2012, 36(5):742-754.

25. Dinarello CA: Immunological and inflammatory functions of the interleukin-1 family. Annu Rev Immunol 2009, 27:519-550.

26. Parvathenani LK, Tertyshnikova S, Greco CR, Roberts SB, Robertson B, Posmantur R: P2X7 mediates superoxide production in primary microglia and is up-regulated in a transgenic mouse model of Alzheimer's disease. J Biol Chem 2003, 278(15):13309-13317.

27. Dinarello CA: The IL-1 family and inflammatory diseases. Clin Exp Rheumatol 2002, 20(5 Suppl 27):S1-S13.

28. Bevilacqua MP, Stengelin S, Gimbrone MA Jr, Seed B: Endothelial leukocyte adhesion molecule 1: an inducible receptor for neutrophils related to complement regulatory proteins and lectins. Science 1989, 243(4895):1160-1165.

29. Chen CJ, Kono H, Golenbock D, Reed G, Akira S, Rock KL: Identification of a key pathway required for the sterile inflammatory response triggered by dying cells. Nat Med 2007, 13(7):851-856

30. Kavita U, Mizel SB: Differential sensitivity of interleukin-1 alpha and -beta precursor proteins to cleavage by calpain, a calcium-dependent protease. J Biol Chem 1995, 270(46):27758-27765.

31. Yazdi AS, Drexler SK: Regulation of interleukin 1alpha secretion by inflammasomes. Ann Rheum Dis 2013, 72(Suppl 2):ii96-ii99.

32. Gross $O$, Yazdi AS, Thomas CJ, Masin M, Heinz LX, Guarda G, Quadroni M, Drexler SK, Tschopp J: Inflammasome activators induce interleukin-1alpha secretion via distinct pathways with differential requirement for the protease function of caspase-1. Immunity 2012, 36(3):388-400.

33. Ferrari D, Pizzirani C, Adinolfi E, Lemoli RM, Curti A, Idzko M, Panther E, di Virgilio F: The P2X7 receptor: a key player in IL-1 processing and release. $\mathrm{J}$ Immunol 2006, 176(7):3877-3883.

34. Thornberry NA, Bull HG, Calaycay JR, Chapman KT, Howard AD, Kostura MJ, Miller DK, Molineaux SM, Weidner JR, Aunins J, et al: A novel heterodimeric cysteine protease is required for interleukin-1 beta processing in monocytes. Nature 1992, 356(6372):768-774

35. Mackenzie A Wilson HL, Kiss-Toth E, Dower SK, North RA, Surprenant A: Rapid secretion of interleukin-1 beta by microvesicle shedding. Immunity 2001, 15(5):825-835.

36. Dinarello CA: Interleukin-18 and the pathogenesis of inflammatory diseases. Semin Nephrol 2007, 27(1):98-114.

37. Chung $Y$, Chang SH, Martinez GJ, Yang XO, Nurieva R, Kang HS, Ma L, Watowich SS, Jetten AM, Tian Q, et al: Critical regulation of early Th17 cell differentiation by interleukin-1 signaling. Immunity 2009, 30(4):576-587. 
38. Sola-Villa D, Camacho M, Sola R, Soler M, Diaz JM, Vila L: IL-1beta induces VEGF, independently of PGE2 induction, mainly through the PI3-K/mTOR pathway in renal mesangial cells. Kidney Int 2006, 70(11):1935-1941.

39. Myers $\mathrm{CL}$, Wertheimer SJ, Schembri-King J, Parks T, Wallace RW: Induction of ICAM-1 by TNF-alpha, IL-1 beta, and LPS in human endothelial cells after downregulation of PKC. Am J Physiol 1992, 263(4 Pt 1):C767-C772.

40. Yang CM, Luo SF, Hsieh HL, Chi PL, Lin CC, Wu CC, Hsiao LD: Interleukin1beta induces ICAM-1 expression enhancing leukocyte adhesion in human rheumatoid arthritis synovial fibroblasts: involvement of ERK, JNK, AP-1, and NF-kappaB. J Cell Physiol 2010, 224(2):516-526.

41. Wang $X$, Feuerstein GZ, Gu JL, Lysko PG, Yue TL: Interleukin-1 beta induces expression of adhesion molecules in human vascular smooth muscle cells and enhances adhesion of leukocytes to smooth muscle cells. Atherosclerosis 1995, 115(1):89-98.

42. Ren G, Zhao X, Zhang L, Zhang J, L'Huillier A, Ling W, Roberts Al, Le AD, Shi $S$, Shao $C$, et al: Inflammatory cytokine-induced intercellular adhesion molecule- 1 and vascular cell adhesion molecule- 1 in mesenchymal stem cells are critical for immunosuppression. J Immunol 2010, 184(5):2321-2328

43. Furuichi K, Wada T, Iwata Y, Kokubo S, Hara A, Yamahana J, Sugaya T, Iwakura $Y$, Matsushima $K$, Asano M, et al: Interleukin-1-dependent sequential chemokine expression and inflammatory cell infiltration in ischemia-reperfusion injury. Crit Care Med 2006, 34(9):2447-2455.

44. Haq M, Norman J, Saba SR, Ramirez G, Rabb H: Role of IL-1 in renal ischemic reperfusion injury. J Am Soc Nephrol 1998, 9(4):614-619.

45. Rusai K, Huang H, Sayed N, Strobl M, Roos M, Schmaderer C, Heemann U, Lutz J: Administration of interleukin-1 receptor antagonist ameliorates renal ischemia-reperfusion injury. Transpl Int 2008, 21(6):572-580

46. Chen A, Sheu LF, Chou WY, Tsai SC, Chang DM, Liang SC, Lin FG, Lee WH: Interleukin-1 receptor antagonist modulates the progression of a spontaneously occurring IgA nephropathy in mice. Am J Kidney Dis 1997 30(5):693-702.

47. Lichtnekert J, Kulkarni OP, Mulay SR, Rupanagudi KV, Ryu M, Allam R, Vielhauer V, Muruve D, Lindenmeyer MT, Cohen CD, et al: Anti-GBM glomerulonephritis involves IL-1 but is independent of NLRP3/ASC inflammasome-mediated activation of caspase-1. PLoS One 2011. 6(10):e26778.

48. Timoshanko JR, Kitching AR, Iwakura Y, Holdsworth SR, Tipping PG: Contributions of IL-1 beta and IL-1alpha to crescentic glomerulonephritis in mice. J Am Soc Nephrol 2004, 15(4):910-918.

49. Hacham M, Argov S, White RM, Segal S, Apte RN: Different patterns of interleukin-1alpha and interleukin-1beta expression in organs of normal young and old mice. Eur Cytokine Netw 2002, 13(1):55-65.

50. Hammerberg C, Arend WP, Fisher GJ, Chan LS, Berger AE, Haskill JS, Voorhees JJ, Cooper KD: Interleukin-1 receptor antagonist in normal and psoriatic epidermis. J Clin Invest 1992, 90(2):571-583.

51. Kurt-Jones EA, Beller DI, Mizel SB, Unanue ER: Identification of a membrane-associated interleukin 1 in macrophages. Proc Natl Acad Sci USA 1985, 82(4):1204-1208.

52. Kaplanski G, Farnarier C, Kaplanski S, Porat R, Shapiro L, Bongrand P, Dinarello CA Interleukin-1 induces interleukin-8 secretion from endothelial cells by a juxtacrine mechanism. Blood 1994, 84(12):4242-4248.

53. Hurgin V, Novick D, Werman A, Dinarello CA, Rubinstein M: Antiviral and immunoregulatory activities of IFN-gamma depend on constitutively expressed IL-1alpha. Proc Natl Acad Sci USA 2007, 104(12):5044-5049.

54. Perregaux DG, McNiff P, Laliberte R, Conklyn M, Gabel CA: ATP acts as an agonist to promote stimulus-induced secretion of IL-1 beta and IL-18 in human blood. J Immunol 2000, 165(8):4615-4623.

55. Takeuchi M, Okura T, Mori T, Akita K, Ohta T, Ikeda M, Ikegami H, Kurimoto M: Intracellular production of interleukin-18 in human epithelial-like cell lines is enhanced by hyperosmotic stress in vitro. Cell Tissue Res 1999, 297(3):467-473.

56. Takeda K, Tsutsui H, Yoshimoto T, Adachi O, Yoshida N, Kishimoto T, Okamura H, Nakanishi K, Akira S: Defective NK cell activity and Th1 response in IL-18-deficient mice. Immunity 1998, 8(3):383-390.

57. Tomura M, Maruo S, Mu J, Zhou XY, Ahn HJ, Hamaoka T, Okamura H, Nakanishi K, Clark S, Kurimoto M, et al: Differential capacities of CD4+, CD8 + , and CD4-CD8- T cell subsets to express IL-18 receptor and produce IFN-gamma in response to IL-18. J Immunol 1998, 160(8):3759-3765.

58. Dinarello CA: IL-18: A TH1-inducing, proinflammatory cytokine and new member of the IL-1 family. J Allergy Clin Immunol 1999, 103(1 Pt 1):11-24.
59. Dao T, Ohashi K, Kayano T, Kurimoto M, Okamura H: Interferon-gammainducing factor, a novel cytokine, enhances Fas ligand-mediated cytotoxicity of murine T helper 1 cells. Cell Immunol 1996, 173(2):230-235.

60. Zhang H, Hile KL, Asanuma H, Vanderbrink B, Franke El, Campbell MT, Meldrum KK: IL-18 mediates proapoptotic signaling in renal tubular cells through a Fas ligand-dependent mechanism. Am J Physiol Renal Physiol 2011, 301(1):F171-F178.

61. Wang J, Long Q, Zhang W, Chen N: Protective effects of exogenous interleukin 18-binding protein in a rat model of acute renal ischemiareperfusion injury. Shock 2012, 37(3):333-340.

62. Puren AJ, Razeghi P, Fantuzzi G, Dinarello CA: Interleukin-18 enhances lipopolysaccharide-induced interferon-gamma production in human whole blood cultures. J Infect Dis 1998, 178(6):1830-1834.

63. Kohka H, Yoshino T, Iwagaki H, Sakuma I, Tanimoto T, Matsuo Y, Kurimoto M, Orita K, Akagi T, Tanaka N: Interleukin-18/interferon-gamma-inducing factor, a novel cytokine, up-regulates ICAM-1 (CD54) expression in KG-1 cells. J Leukoc Biol 1998, 64(4):519-527.

64. Ueno N, Kashiwamura S, Ueda H, Okamura H, Tsuji NM, Hosohara K, Kotani J, Marukawa S: Role of interleukin 18 in nitric oxide production and pancreatic damage during acute pancreatitis. Shock 2005, 24(6):564-570.

65. Morel JC, Park CC, Woods JM, Koch AE: A novel role for interleukin-18 in adhesion molecule induction through NF kappa B and phosphatidylinositol (PI) 3-kinase-dependent signal transduction pathways. J Biol Chem 2001, 276(40):37069-37075.

66. Wu H, Craft ML, Wang P, Wyburn KR, Chen G, Ma J, Hambly B, Chadban SJ: IL-18 contributes to renal damage after ischemia-reperfusion. J Am SoC Nephrol 2008, 19(12):2331-2341.

67. Sugiyama M, Kinoshita K, Kishimoto K, Shimazu H, Nozaki Y, Ikoma S, Funauchi M: Deletion of IL-18 receptor ameliorates renal injury in bovine serum albumin-induced glomerulonephritis. Clin Immunol 2008, 128(1):103-108.

68. Bani-Hani AH, Leslie JA, Asanuma H, Dinarello CA, Campbell MT, Meldrum DR, Zhang H, Hile K, Meldrum KK: IL-18 neutralization ameliorates obstructioninduced epithelial-mesenchymal transition and renal fibrosis. Kidney Int 2009, 76(5):500-511.

69. Bergsbaken T, Cookson BT: Macrophage activation redirects yersiniainfected host cell death from apoptosis to caspase-1-dependent pyroptosis. PLoS Pathog 2007, 3(11):e161.

70. Taylor SR, Gonzalez-Begne M, Dewhurst S, Chimini G, Higgins CF, Melvin JE, Elliott JI: Sequential shrinkage and swelling underlie P2X7-stimulated lymphocyte phosphatidylserine exposure and death. J Immunol 2008, 180(1):300-308.

71. Bryan NB, Dorfleutner A, Kramer SJ, Yun C, Rojanasakul Y, Stehlik C Differential splicing of the apoptosis-associated speck like protein containing a caspase recruitment domain (ASC) regulates inflammasomes. J Inflamm (Lond) 2010, 7:23

72. Dorfleutner A, Bryan NB, Talbott SJ, Funya KN, Rellick SL, Reed JC, Shi X, Rojanasakul Y, Flynn DC, Stehlik C: Cellular pyrin domain-only protein 2 is a candidate regulator of inflammasome activation. Infect Immun 2007 75(3):1484-1492.

73. Imamura R, Wang Y, Kinoshita T, Suzuki M, Noda T, Sagara J, Taniguchi S, Okamoto H, Suda T: Anti-inflammatory activity of PYNOD and its mechanism in humans and mice. J Immunol 2010, 184(10):5874-5884.

74. Kersse K, Vanden Berghe T, Lamkanfi M, Vandenabeele P: A phylogenetic and functional overview of inflammatory caspases and caspase-1-related CARD-only proteins. Biochem Soc Trans 2007, 35(Pt 6):1508-1511.

75. Harada H, Chan CM, Loesch A, Unwin R, Burnstock G: Induction of proliferation and apoptotic cell death via $\mathrm{P} 2 \mathrm{Y}$ and $\mathrm{P} 2 \mathrm{X}$ receptors, respectively, in rat glomerular mesangial cells. Kidney Int 2000, 57(3):949-958.

76. Goncalves RG, Gabrich L, Rosario A Jr, Takiya CM, Ferreira ML, Chiarini LB, Persechini PM, Coutinho-Silva R, Leite M Jr: The role of purinergic P2X7 receptors in the inflammation and fibrosis of unilateral ureteral obstruction in mice. Kidney Int 2006, 70(9):1599-1606.

77. Vonend O, Turner CM, Chan CM, Loesch A, Dell'Anna GC, Srai KS, Burnstock $\mathrm{G}$, Unwin RJ: Glomerular expression of the ATP-sensitive P2X receptor in diabetic and hypertensive rat models. Kidney Int 2004, 66(1):157-166.

78. Turner CM, Tam FW, Lai PC, Tarzi RM, Burnstock G, Pusey CD, Cook HT, Unwin RJ: Increased expression of the pro-apoptotic ATP-sensitive P2X7 receptor in experimental and human glomerulonephritis. Nephrol Dial Transplant 2007, 22(2):386-395. 
79. Deplano S, Cook HT, Russell R, Franchi L, Schneiter S, Bhangal G, Unwin RJ, Pusey CD, Tam FW, Behmoaras J: P2X7 receptor-mediated NIrp3inflammasome activation is a genetic determinant of macrophagedependent crescentic glomerulonephritis. J Leukoc Biol 2013, 93(1):127-134.

80. Vilaysane A, Chun J, Seamone ME, Wang W, Chin R, Hirota S, Li Y, Clark SA Tschopp J, Trpkov K, et al: The NLRP3 inflammasome promotes renal inflammation and contributes to CKD. J Am Soc Nephrol 2010, 21(10):1732-1744.

81. Iyer SS, Pulskens WP, Sadler JJ, Butter LM, Teske GJ, Ulland TK, Eisenbarth SC, Florquin S, Flavell RA, Leemans JC, et al: Necrotic cells trigger a sterile inflammatory response through the Nlrp3 inflammasome. Proc Natl Acad Sci USA 2009, 106(48):20388-20393.

82. Jalilian I, Spildrejorde M, Seavers A, Curtis BL, McArthur JD, Sluyter R: Functional expression of the damage-associated molecular pattern receptor P2X7 on canine kidney epithelial cells. Vet Immunol Immunopathol 2012, 150(3-4):228-233.

83. Yamagishi H, Yokoo T, Imasawa T, Mitarai T, Kawamura T, Utsunomiya Y: Genetically modified bone marrow-derived vehicle cells site specifically deliver an anti-inflammatory cytokine to inflamed interstitium of obstructive nephropathy. J Immunol 2001, 166(1):609-616.

84. Matsumoto K, Dowling J, Atkins RC: Production of interleukin 1 in glomerular cell cultures from patients with rapidly progressive crescentic glomerulonephritis. Am J Nephrol 1988, 8(6):463-470.

85. Tam FW, Smith J, Cashman SJ, Wang Y, Thompson EM, Rees AJ: Glomerular expression of interleukin-1 receptor antagonist and interleukin-1 beta genes in antibody-mediated glomerulonephritis. Am J Pathol 1994, 145(1):126-136.

86. Lan HY, Nikolic-Paterson DJ, Mu W, Vannice JL, Atkins RC: Interleukin-1 receptor antagonist halts the progression of established crescentic glomerulonephritis in the rat. Kidney Int 1995, 47(5):1303-1309.

87. Karkar AM, Koshino Y, Cashman SJ, Dash AC, Bonnefoy J, Meager A, Rees AJ: Passive immunization against tumour necrosis factor-alpha (TNF-alpha) and IL-1 beta protects from LPS enhancing glomerular injury in nephrotoxic nephritis in rats. Clin Exp Immunol 1992, 90(2):312-318.

88. Karkar AM, Tam FW, Steinkasserer A, Kurrle R, Langner K, Scallon BJ, Meager A, Rees AJ: Modulation of antibody-mediated glomerular injury in vivo by IL-1ra, soluble IL-1 receptor, and soluble TNF receptor. Kidney Int 1995, 48(6):1738-1746

89. Tam FW, Karkar AM, Smith J, Yoshimura T, Steinkasserer A, Kurrle R, Langner K, Rees AJ: Differential expression of macrophage inflammatory protein-2 and monocyte chemoattractant protein-1 in experimental glomerulonephritis. Kidney Int 1996, 49(3):715-721.

90. Schorlemmer HU, Kanzy EJ, Langner KD, Kurrle R: Immunoregulation of SLE-like disease by the IL-1 receptor: disease modifying activity on BDF1 hybrid mice and MRL autoimmune mice. Agents Actions 1993, 39 Spec No:C117-C120.

91. Granfeldt A, Ebdrup L, Tonnesen E, Wogensen L: Renal cytokine profile in an endotoxemic porcine model. Acta Anaesthesiol Scand 2008, 52(5):614-620

92. Hertting O, Khalil A, Jaremko G, Chromek M, Li YH, Bakhiet M, Bartfai T, Tullus K, Brauner A: Enhanced chemokine response in experimental acute Escherichia coli pyelonephritis in IL-1beta-deficient mice. Clin Exp Immunol 2003, 131(2):225-233.

93. Homsi E, Janino P, de Faria JB: Role of caspases on cell death, inflammation, and cell cycle in glycerol-induced acute renal failure. Kidney Int 2006, 69(8):1385-1392.

94. Wang W, Faubel S, Ljubanovic D, Mitra A, Falk SA, Kim J, Tao Y, Soloviev A, Reznikov LL, Dinarello CA, et al: Endotoxemic acute renal failure is attenuated in caspase-1-deficient mice. Am J Physiol Renal Physiol 2005 288(5):F997-F1004

95. Gauer S, Sichler O, Obermuller N, Holzmann Y, Kiss E, Sobkowiak E, Pfeilschifter J, Geiger H, Muhl H, Hauser IA: IL-18 is expressed in the intercalated cell of human kidney. Kidney Int 2007, 72(9):1081-1087.

96. Edelstein CL, Hoke TS, Somerset H, Fang W, Klein CL, Dinarello CA, Faubel S: Proximal tubules from caspase-1-deficient mice are protected against hypoxia-induced membrane injury. Nephrol Dial Transplant 2007, 22(4):1052-1061

97. Kinoshita K, Yamagata T, Nozaki Y, Sugiyama M, Ikoma S, Funauchi M, Kanamaru A: Blockade of IL-18 receptor signaling delays the onset of autoimmune disease in MRL-Faslpr mice. J Immunol 2004, 173(8):5312-5318.
98. VanderBrink BA, Asanuma H, Hile K, Zhang H, Rink RC, Meldrum KK: Interleukin-18 stimulates a positive feedback loop during renal obstruction via interleukin-18 receptor. J Urol 2011, 186(4):1502-1508.

99. Nuki G, Bresnihan B, Bear MB, McCabe D: Long-term safety and maintenance of clinical improvement following treatment with anakinra (recombinant human interleukin-1 receptor antagonist) in patients with rheumatoid arthritis: extension phase of a randomized, double-blind, placebo-controlled trial. Arthritis Rheum 2002, 46(11):2838-2846.

100. Sumpter KM, Adhikari S, Grishman EK, White PC: Preliminary studies related to anti-interleukin-1beta therapy in children with newly diagnosed type 1 diabetes. Pediatr Diabetes 2011, 12(7):656-667.

101. Economides AN, Carpenter LR, Rudge JS, Wong V, Koehler-Stec EM, Hartnett C, Pyles EA, Xu X, Daly TJ, Young MR, et al: Cytokine traps: multi-component, high-affinity blockers of cytokine action. Nat Med 2003, 9(1):47-52.

102. Goldbach-Mansky R, Shroff SD, Wilson M, Snyder C, Plehn S, Barham B, Pham TH, Pucino F, Wesley RA, Papadopoulos $\mathrm{JH}$, et al: A pilot study to evaluate the safety and efficacy of the long-acting interleukin-1 inhibitor rilonacept (interleukin-1 Trap) in patients with familial cold autoinflammatory syndrome. Arthritis Rheum 2008, 58(8):2432-2442.

103. Hoffman HM, Throne ML, Amar NJ, Sebai M, Kivitz AJ, Kavanaugh A, Weinstein SP, Belomestnov P, Yancopoulos GD, Stahl N, et al: Efficacy and safety of rilonacept (interleukin-1 Trap) in patients with cryopyrinassociated periodic syndromes: results from two sequential placebocontrolled studies. Arthritis Rheum 2008, 58(8):2443-2452.

104. Lachmann HJ, Kone-Paut I, Kuemmerle-Deschner JB, Leslie KS, Hachulla E, Quartier P, Gitton X, Widmer A, Patel N, Hawkins PN: Use of canakinumab in the cryopyrin-associated periodic syndrome. N Engl J Med 2009, 360(23):2416-2425.

105. Alten $R$, Gram H, Joosten LA, van den Berg WB, Sieper J, Wassenberg S, Burmester G, van Riel P, Diaz-Lorente M, Bruin GJ, et al: The human anti-IL-1 beta monoclonal antibody ACZ885 is effective in joint inflammation models in mice and in a proof-of-concept study in patients with rheumatoid arthritis. Arthritis Res Ther 2008, 10(3):R67.

106. So A, de Smedt T, Revaz S, Tschopp J: A pilot study of IL-1 inhibition by anakinra in acute gout. Arthritis Res Ther 2007, 9(2):R28.

107. Dostert C, Petrilli V, van Bruggen R, Steele C, Mossman BT, Tschopp J: Innate immune activation through Nalp3 inflammasome sensing of asbestos and silica. Science 2008, 320(5876):674-677.

108. Nordstrom D, Knight A, Luukkainen R, van Vollenhoven R, Rantalaiho V, Kajalainen A, Brun JG, Proven A, Ljung L, Kautiainen $\mathrm{H}$, et al: Beneficial effect of interleukin 1 inhibition with Anakinra in adult-onset Still's disease. An open, randomized, multicenter study. J Rheumatol 2012, 39(10):2008-2011.

109. Pascual V, Allantaz F, Arce E, Punaro M, Banchereau J: Role of interleukin(IL-1) in the pathogenesis of systemic onset juvenile idiopathic arthritis and clinical response to IL-1 blockade. J Exp Med 2005, 201(9):1479-1486.

110. Arulkumaran N, Unwin RJ, Tam FW: A potential therapeutic role for P2X7 receptor (P2X7R) antagonists in the treatment of inflammatory diseases. Expert Opin Investig Drugs 2011, 20(7):897-915.

111. Dell'Antonio G, Quattrini A, Dal Cin E, Fulgenzi A, Ferrero ME: Antinociceptive effect of a new P(2Z)/P2X7 antagonist, oxidized ATP, in arthritic rats. Neurosci Lett 2002, 327(2):87-90.

112. Dell'Antonio G, Quattrini A, Cin ED, Fulgenzi A, Ferrero ME: Relief of inflammatory pain in rats by local use of the selective P2X7 ATP receptor inhibitor, oxidized ATP. Arthritis Rheum 2002, 46(12):3378-3385.

113. Taylor SR, Turner CM, Elliott J, MCDaid J, Hewitt R, Smith J, Pickering MC, Whitehouse DL, Cook HT, Burnstock G, et al: P2X7 deficiency attenuates renal injury in experimental glomerulonephritis. J Am Soc Nephrol 2009, 20(6):1275-1281.

114. Wareham K, Vial C, Wykes RC, Bradding P, Seward EP: Functional evidence for the expression of $\mathrm{P} 2 \mathrm{X} 1, \mathrm{P} 2 \mathrm{X} 4$ and $\mathrm{P} 2 \mathrm{X} 7$ receptors in human lung mast cells. Br J Pharmacol 2009, 157(7):1215-1224.

115. Kolliputi N, Shaik RS, Waxman AB: The inflammasome mediates hyperoxiainduced alveolar cell permeability. J Immunol 2010, 184(10):5819-5826.

116. Fernando SL, Saunders BM, Sluyter R, Skarratt KK, Goldberg H, Marks GB, Wiley JS, Britton WJ: A polymorphism in the P2X7 gene increases susceptibility to extrapulmonary tuberculosis. Am J Respir Crit Care Med 2007, 175(4):360-366.

117. Keystone EC, Wang MM, Layton M, Hollis S, McInnes IB: Clinical evaluation of the efficacy of the P2X7 purinergic receptor antagonist AZD9056 on 
the signs and symptoms of rheumatoid arthritis in patients with active disease despite treatment with methotrexate or sulphasalazine. Ann Rheum Dis 2012, 71(10):1630-1635.

118. Cornelis S, Kersse K, Festjens N, Lamkanfi M, Vandenabeele P: Inflammatory caspases: targets for novel therapies. Curr Pharm Des 2007, 13(4):367-385.

119. Turner CM, Ramesh B, Srai SK, Burnstock G, Unwin RJ: Altered ATP-sensitive $\mathrm{P} 2$ receptor subtype expression in the Han:SPRD cy/+ rat, a model of autosomal dominant polycystic kidney disease. Cells Tissues Organs 2004 178(3):168-179.

120. von Bernuth H, Picard C, Jin Z, Pankla R, Xiao H, Ku CL, Chrabieh M, Mustapha IB, Ghandil P, Camcioglu Y, et al: Pyogenic bacterial infections in humans with MyD88 deficiency. Science 2008, 321(5889):691-696.

121. Mulay SR, Kulkarni OP, Rupanagudi KV, Migliorini A, Darisipudi MN, Vilaysane A, Muruve D, Shi Y, Munro F, Liapis H, et al: Calcium oxalate crystals induce renal inflammation by NLRP3-mediated IL-1beta secretion. J Clin Invest 2013, 123(1):236-246.

122. Knauf F, Asplin JR, Granja I, Schmidt IM, Moeckel GW, David RJ, Flavell RA, Aronson PS: NALP3-mediated inflammation is a principal cause of progressive renal failure in oxalate nephropathy. Kidney Int 2013, 84(5):895-901

123. Shigeoka AA, Mueller JL, Kambo A, Mathison JC, King AJ, Hall WF, Correia Jda S, Ulevitch RJ, Hoffman HM, McKay DB: An inflammasomeindependent role for epithelial-expressed NIrp3 in renal ischemiareperfusion injury. J Immunol 2010, 185(10):6277-6285.

124. Fujita T, Ogihara N, Kamura Y, Satomura A, Fuke Y, Shimizu C, Wada Y, Matsumoto K: Interleukin-18 contributes more closely to the progression of diabetic nephropathy than other diabetic complications. Acta Diabetol 2012, 49(2):111-117.

125. Siew ED, Ikizler TA, Gebretsadik T, Shintani A, Wickersham N, Bossert F, Peterson JF, Parikh CR, May AK, Ware LB: Elevated urinary IL-18 levels at the time of ICU admission predict adverse clinical outcomes. Clin J Am Soc Nephrol 2010, 5(8):1497-1505

126. Parikh CR, Mishra J, Thiessen-Philbrook H, Dursun B, Ma Q, Kelly C, Dent C, Devarajan P, Edelstein CL: Urinary IL-18 is an early predictive biomarker of acute kidney injury after cardiac surgery. Kidney Int 2006, 70(1):199-203.

127. Turkmen F, Isitmangil G, Berber I, Arslan G, Sevinc C, Ozdemir A: Comparison of serum creatinine and spot urine interleukin-18 levels following radiocontrast administration. Indian J Nephrol 2012, 22(3):196-199.

128. Mizobuchi M, Towler D, Slatopolsky E: Vascular calcification: the killer of patients with chronic kidney disease. J Am Soc Nephrol 2009, 20(7):1453-1464.

129. Gangemi S, Mallamace A, Minciullo PL, Santoro D, Merendino RA, Savica V, Bellinghieri G: Involvement of interleukin-18 in patients on maintenance haemodialysis. Am J Nephrol 2002, 22(5-6):417-421.

130. Fukami A, Yamagishi S, Adachi H, Matsui T, Yoshikawa K, Ogata K, Kasahara A, Tsukagawa E, Yokoi K, Imaizumi T: High white blood cell count and low estimated glomerular filtration rate are independently associated with serum level of monocyte chemoattractant protein-1 in a general population. Clin Cardiol 2011, 34(3):189-194.

131. Ranjbaran H, Sokol SI, Gallo A, Eid RE, lakimov AO, D'Alessio A, Kapoor JR, Akhtar S, Howes CJ, Aslan M, et al: An inflammatory pathway of IFN-gamma production in coronary atherosclerosis. J Immunol 2007, 178(1):592-604.

132. Whitman SC, Ravisankar P, Daugherty A: Interleukin-18 enhances atherosclerosis in apolipoprotein $\mathrm{E}(-/-)$ mice through release of interferon-gamma. Circ Res 2002, 90(2):E34-E38.

133. Mallat Z, Corbaz A, Scoazec A, Besnard S, Leseche G, Chvatchko Y, Tedgui A: Expression of interleukin-18 in human atherosclerotic plaques and relation to plaque instability. Circulation 2001, 104(14):1598-1603.

134. Porazko T, Kuzniar J, Kusztal M, Kuzniar TJ, Weyde W, Kuriata-Kordek M, Klinger M: IL-18 is involved in vascular injury in end-stage renal disease patients. Nephrol Dial Transplant 2009, 24(2):589-596.

135. Covic A, Haydar AA, Bhamra-Ariza P, Gusbeth-Tatomir P, Goldsmith DJ: Aortic pulse wave velocity and arterial wave reflections predict the extent and severity of coronary artery disease in chronic kidney disease patients. J Nephrol 2005, 18(4):388-396.

136. Arulkumaran N, Annear NM, Singer M: Patients with end-stage renal disease admitted to the intensive care unit: systematic review. $\mathrm{Br} J$ Anaesth 2013, 110(1):13-20
137. le Meur Y, Lorgeot V, Aldigier JC, Wijdenes J, Leroux-Robert C, Praloran V: Whole blood production of monocytic cytokines (IL-1beta, IL-6, TNF-alpha, sIL-6R, IL-1Ra) in haemodialysed patients. Nephrol Dial Transplant 1999, 14(10):2420-2426.

138. Pereira BJ, Shapiro L, King AJ, Falagas ME, Strom JA, Dinarello CA: Plasma levels of IL-1 beta, TNF alpha and their specific inhibitors in undialyzed chronic renal failure, CAPD and hemodialysis patients. Kidney Int 1994, 45(3):890-896.

doi:10.1186/1471-2369-15-21

Cite this article as: Turner et al:: Is the inflammasome a potential therapeutic target in renal disease?. BMC Nephrology 2014 15:21.

\section{Submit your next manuscript to BioMed Central and take full advantage of:}

- Convenient online submission

- Thorough peer review

- No space constraints or color figure charges

- Immediate publication on acceptance

- Inclusion in PubMed, CAS, Scopus and Google Scholar

- Research which is freely available for redistribution

Submit your manuscript at www.biomedcentral.com/submit
C Biomed Central 